\title{
Historical floods of the Douro River in Porto, Portugal (1727-1799)
}

\author{
Maria João Alcoforado ${ }^{1}$ (D) - Luís Pedro Silva ${ }^{2}$ (D) - Inês Amorim ${ }^{3}$ (D) \\ Marcelo Fragoso ${ }^{1}$ (D) - João Carlos Garcia ${ }^{4}$ (D)
}

Received: 24 April 2020 / Accepted: 5 January 2021 /Published online: 15 March 2021

(C) The Author(s) 2021

\begin{abstract}
Extreme meteorological events have had devastating consequences all over the world throughout the ages. In this study, we look into the floods at the mouth of the Douro River (Porto, Portugal) in the eighteenth century to expand the data series of floods in Northern Portugal. Information was gathered mostly from documentary narrative sources, either individual or institutional (administrative and ecclesiastic), some of which include reports of Pro Serenitate ceremonies. A study by the priest Rebelo Costa (1789) and the memories of the merchant Ignacio Henckell from 1717 to 1800 stand out among the individual sources. We concluded that there was great interannual variability in the occurrence of the 54 recorded floods, the highest number of which occurred in the 1780s. The "catastrophic" floods were recorded in 1727, 1739, 1769, 1774, 1777, 1788 and 1798 , four of which are studied in detail in this paper. The greatest number of flood events took place in winter and autumn, and most of them lasted between 1 and 3 days. An analysis of the description of the floods, their impacts and the associated meteorological causes was carried out. In most cases, the frontal activity associated with Atlantic cyclonic systems was the cause of positive precipitation anomalies in NW Iberia. The great variability in heavy precipitation was confirmed by the new data. However, hardly any temporal simultaneity was found with other case studies in Southern Europe, except for Spain, especially several localities of Galicia and the mid Douro Valley (Zamora).
\end{abstract}

Keywords Floods · Meteorological extremes · Eighteenth century $\cdot$ Douro River · Porto · Portugal

\section{Introduction}

Extreme meteorological events, such as heavy precipitation or long-lasting drought events, have had devastating consequences throughout the ages all over the world. In a period, when

Maria João Alcoforado

mjalcoforado@campus.ul.pt

Extended author information available on the last page of the article 
climate change issues are of utmost importance for humankind, scientists are devoted to create databases of those events and their consequences. River floods are "among the most costly natural hazards" (Blöschl et al. 2019), unfortunately giving rise to human deaths and infrastructure destruction. Several authors have been studying historical floods and their impacts from China (Luo 1987), to Europe (Brázdil et al. 2006) and South America (Prieto and GarcíaHerrera 2009). To address the need for improved historical data, scholars have used a very broad range of documentary evidence, which contain very detailed descriptions of these events (Barriendos and Rodrigo 2006; Glaser et al. 2010).

In order "to gain insight into long term flood regime dynamics", Hall et al. (2014) discuss flood regimes changes in Europe and suggest the future combination of systematic instrumental and documentary flood data, whereas Hall et al. (2015) present a European flood database for the period 1960-2000. Bertola et al. (2020) used this panEuropean flood database and found negative trends in flood magnitude in Southern Europe, particularly in large catchments, while Blöschl et al. (2019) conclude that the flood changes observed for the same period are consistent with climate model projections for 2100 .

Hall et al. (2014) and Kjeldsen et al. (2014) state that historical records of floods are important to get a long-term perspective of current flood events and to improve future climate projections. Luino et al. (2002) and Cœur and Lang (2008), among many others, consider that reconstructed past extreme flood events may be used to land planning, including flood risk mitigation and present examples of application in different places of France and Italy.

This paper is a contribution to the above approach. Its main purpose is to reconstruct a highresolution history of floods that occurred on the estuary of the Douro River (near the city of Porto, North Portugal, NW Iberia) during the eighteenth century. As there are hardly any divulged flood data concerning the Portuguese rivers in this period, this new and valuable information may be of use to the European database referred above (Hall et al. 2015) and to regional flood risk management (Cœur and Lang 2008).

The floods of the Douro River have always been a recurrent phenomenon (Velhas 1997; Aires et al. 2000; Santos et al. 2018). The levels of high waters near the Douro mouth can be seen on buildings and walls in downtown Porto, as well on the river right bank (outskirts of the city) and the left one (Vila Nova de Gaia). However, most imprints date back to the nineteenth and twentieth centuries. This is why we looked for flood information for the early modern period, more precisely the eighteenth century, to help produce a longer series of flood episodes of the Douro River in Porto. The main information was extracted from documentary narrative sources, either individual or institutional (administrative and ecclesiastic), that are written testimonials of the events and their consequences.

Therefore, the specific objectives of this paper are (1) to compile a catalogue of floods of the Douro River at Porto throughout the eighteenth century, (2) to provide a classification of flood magnitude according to stage and damages, (3) to analyse the atmospheric situation associated to the most extreme floods and (4) to compare the dates of these floods with those in other European areas, mostly in the context of other Iberian river catchments.

\section{Study area}

The Douro River spring is located in the Urbión Mountains (Sória, Spain), $1700 \mathrm{~m}$ above sea level and its mouth in the Atlantic Ocean, $927 \mathrm{~km}$ downstream, near the city of Porto, Portugal 
(Fig. 1). Its hydrographical basin is the largest of the Iberian Peninsula: $97,603 \mathrm{~km}^{2}(81 \%$ of which lies in Spain and 19\% in Portugal) (Soares and Bateira 2020).

The following description focuses on the Portuguese section of the Douro basin and the hydrometeorological conditions associated with flooding in the Douro River mouth. In Portugal, the Douro flows in a deep and narrow valley, and the longitudinal profiles of its tributaries are very steep in some sections. Consequently, the water level rises very fast and dangerously, following intense precipitation (Velhas 1997). Moreover, infiltration rates of precipitation are only circa $10 \%$ (Conceição 2008) due to the predominant lithology of the Douro basin mainly represented by metamorphic and granitic rocks, intensely deformed during the Variscan orogeny (Antón et al. 2012).

The Atlantic coast at the Douro mouth experiences a semi-diurnal mesotidal regime (Araújo et al. 2013) that plays an important role in the flood stage in the lower Douro, namely at Porto. Nowadays, the maximum height of high tide attains $4.2 \mathrm{~m}$ over the hydrographical zero, and the minimum only reaches $0.3 \mathrm{~m}$ (Tide tables of Porto). The configuration of the estuary, of vestibular type, hinders the river flow as although it is rather broad $6 \mathrm{~km}$ upstream, it narrows sharply at the river mouth. Sandy tidal deltas also develop inside the estuary (in the vestibular lagoon) and outside of the estuarine channel. Furthermore, at the estuarine mouth, an area (restinga) made of a deposit of coarse sand and boulders develops northwards (Jesus 2003). It is called Cabedelo do Douro, and it is sometimes overflowed by the storm waves and the tidal currents when they occur during the high tides (Suppl. Fig. 1).

Naturally, the floods taking place at the mouth of the Douro River depend also greatly on the rainfall that falls in the whole basin of the Douro and its tributaries (Conceição 2008). Indeed, the climate of the Douro basin is Atlantic in its westernmost area, with rainy and rather cold winters and dry and mild summers; the climate becomes Mediterranean eastwards towards the border and more "continental" in Spain. According to Daveau (1977), the mean

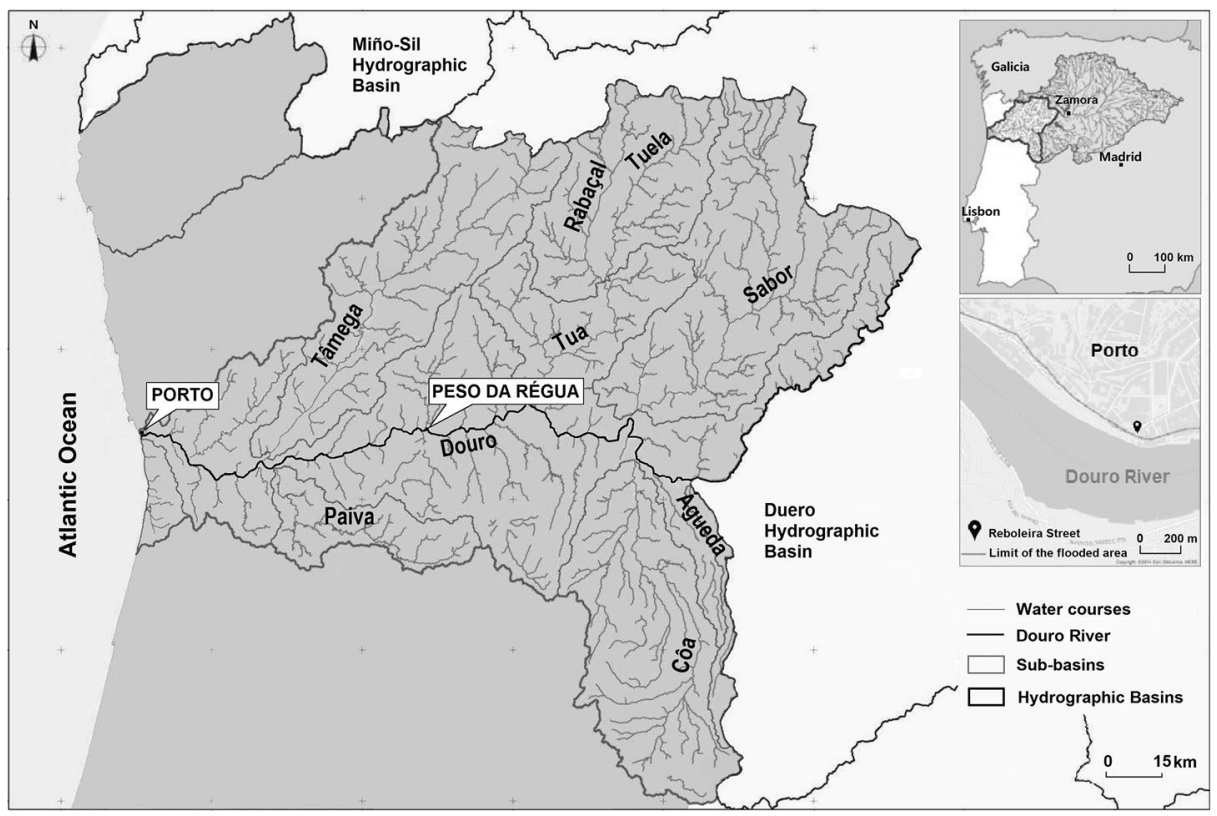

Fig. 1 The Douro Hydrographic Region. Source: APA 2012 [adapted] 
annual precipitation varies from $500 \mathrm{~mm}$ in the NE part of the country (Douro and its tributaries, e.g. Tua and Sabor rivers) to more than $2500 \mathrm{~mm}$ in the NW mountains, from where some other tributaries flow, such as the Tâmega river (Fig. 1). The west-east huge precipitation contrast is due to the relief effect of the high NW ranges concordant with the coastline, which prevents the Atlantic humid air masses from reaching their leeward side.

The annual precipitation in Porto/Serra do Pilar (Porto/SP-lat: $41^{\circ} 08^{\prime}$; long: $08^{\circ} 36^{\prime} \mathrm{W}$; alt: $93 \mathrm{~m}$ ) reaches $1253 \mathrm{~mm}$ in the "normal" 1981-2010 period (http://www.ipma.pt/pt/oclima/ normais.clima/1971-2000/014/). The rainfall regime in Porto (Suppl. Fig. 2) is characterized by a wet season from October to March with a maximum in December (195 mm) and a 3month dry period spanning from June to August; July is the driest month with less than 20-mm rainfall. April, May and September are transition months. During the 1981-2010 period, the maximum daily rainfall attained $150.5 \mathrm{~mm}$ in October, exceeding the monthly average for that month $(138 \mathrm{~mm})$. In March, the daily maximum $(110.3 \mathrm{~mm})$ was also higher than the monthly average $(90 \mathrm{~mm})$. Santos et al. (2018) pointed out that the cyclonic weather type is the most favourable to the occurrence of storms causing destructive floods in Northern Portugal. This weather type is generally associated with SW flow, high instability and advection of humid air masses towards Portugal. Moreover, Velhas (1997) states that long-lasting western flow creates favourable conditions for the overlapping of the flow from the different tributaries along the Douro River (Fig. 1) during flood peaks.

Precipitation in the Porto region has a direct influence in increasing the Douro flow near its mouth. The hydrological regime of the Douro River in Peso da Régua, $70 \mathrm{~km}$ upstream from Porto (Fig.1), is driven by this annual rainfall pattern with maximum discharges occurring in January, within a winter period of high streamflow (above $600 \mathrm{~m}^{3} \mathrm{~s}^{-1}$ ). During the dry season, August is the month with the lowest discharges that fall to $80 \mathrm{~m}^{3} \mathrm{~s}^{-1}$, revealing the typical strong seasonality of the Mediterranean hydrological regimes (Suppl. Fig. 2). Dams did not exist in the eighteenth century, but even nowadays they do not have enough capacity to limit the river flow in the case of large floods (Conceição 2008).

In summary, the combination of intense precipitation, high tidal waves and the silting of the river mouth has given rise to severe floods in Porto and Vila Nova de Gaia throughout the ages.

Moreover, Porto downtown inhabitants have been exposed to the floods for centuries, as they lived (and still live) near the Douro bank (Fig. 2). At the beginning of the eighteenth century, Portugal had circa 2 million inhabitants ( 7 to 8 million in Spain). In 1732, 115,000 people lived in Lisbon versus only 34,000 in Porto. However, during the eighteenth century, Porto's population nearly doubled, and the population density was much greater in Porto than in Lisbon: 838 inhabitants per $\mathrm{km}^{2}$ in 1758 (versus 67.6 in Lisbon in 1755) (Osswald 2008).

The parishes of $S$. Nicolau and Sé (marginal to the river) had the highest population densities, as a great number of merchants lived near their working area: the port was an important commercial centre, with infrastructures for storage, loading and unloading goods. Besides Portuguese, there were also English, Flemish, German and Nordic merchants. The trade was based on the import of codfish from North Atlantic, on the import of agricultural and industrial goods and colonial products from Brazil and on the export of Port wine produced on the banks of the Douro River, eastwards from Porto, where the topoclimate is Mediterranean. The inhabitants were aware of the hazard the river floods represented, but they chose to live there and create strategies to cope with high waters. Sometimes these strategies consisted of piers and walls, which contained the high waters up to certain levels but could also contribute to increasing large floods. 


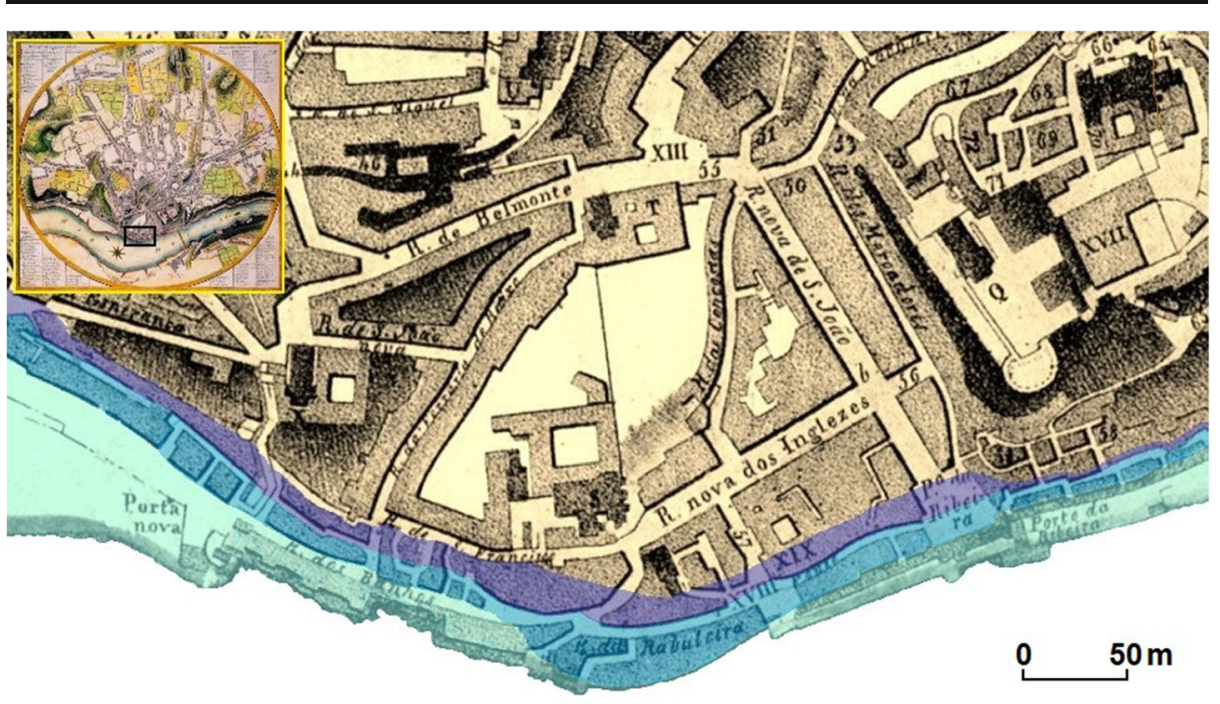

Fig. 2 Areas of the riverine districts of Porto reached by catastrophic floods (violet), extraordinary floods (dark blue) and ordinary floods (light blue) between 1727 and 1799. Cartographic source: Plan of Oporto. London, Neele, 1813

\section{Data and methods}

\subsection{Data}

This study presents the results of a historical reconstruction based on documentary sources (Table 1). We used data from primary sources contemporary to the events rather than secondary references. This involved a systematic and extensive consultation of hundreds of archival documents, as each flood event is not well referenced within the sources. The best information on floods and their effects was found in personal diaries.

\subsubsection{Main individual sources}

The data used in this study come mainly from two important individual and original sources: an essay by the priest Rebelo da Costa (?-1791), doctor of theology at Coimbra University, and the diary of the merchant Ignacio Henckell (1712-1802), a German descent that lived in Porto.

The study written by Rebelo da Costa (? - 1791), entitled Topographical and historical description of the city of Porto (Costa 1789), is part of a larger task encouraged by the academies of the epoch. The objective was to identify and disseminate the knowledge about the regions and towns of Portugal, as well as their resources, traditions, activities and population in order to plan the economic future of the country. From this work, we collected descriptions of several floods that occurred in the Douro River during the eighteenth century, especially those of $1727,1729,1739,1774$ and 1788. The floods were most probably witnessed by the author, as the texts include very detailed and vivid accounts of most of them.

However, The memories of Ignacio António Henkel (1717-1800) is the most important individual source. The manuscript is now lost, but it had fortunately been known to Vasco Valente, former director of Porto's Soares dos Reis Fine Arts Museum (Valente 1962). This 


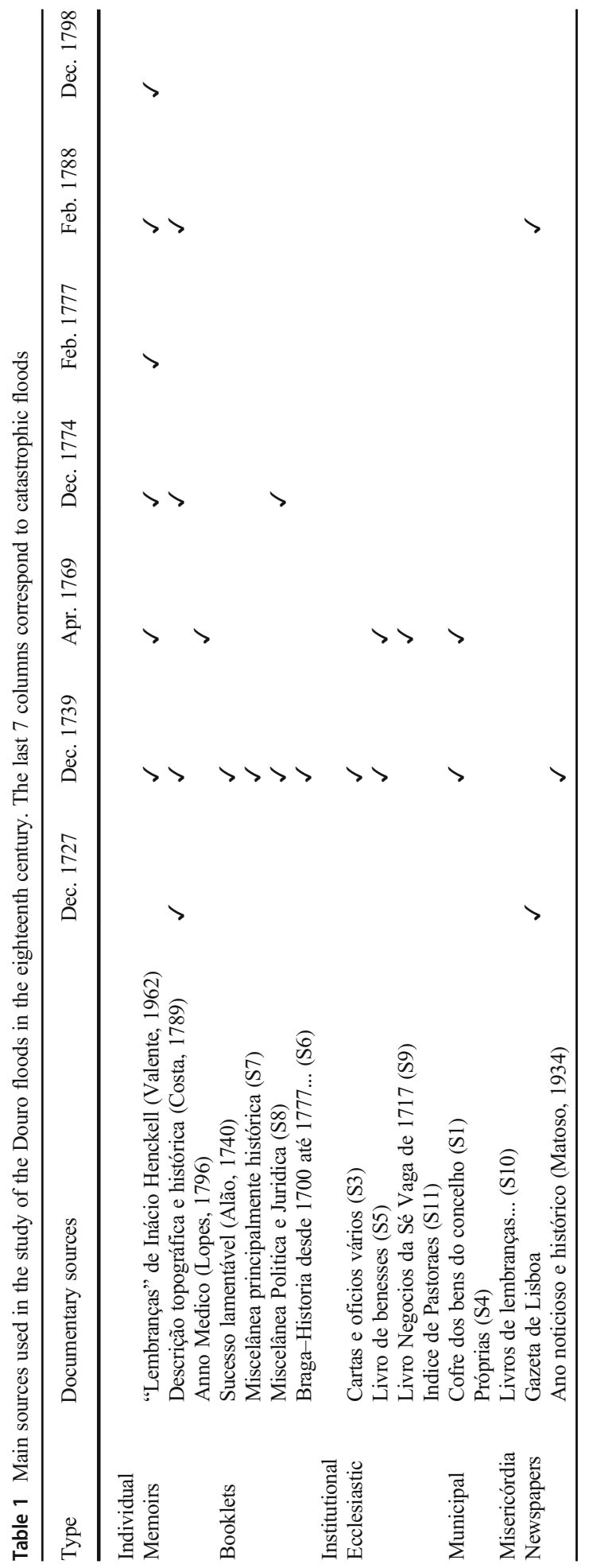


source has been used by several authors (Tato 1966; Fragoso et al. 2015; Amorim et al. 2017; Silva 2019), but the present systematic analysis has revealed precious information about the Douro floods. Henckell (1712-1802) was born in Porto. His father came from Hamburg, where Henckell studied and worked as a merchant from 1723 until 1732. He had personal and family connections with Dutch, English and Hamburg merchants. Henckell lived in the low part of the city, in front of the harbour (Ribeira do Porto), between Rua Nova and Rua da Reboleira (Fig.1), so his life and trades were disturbed by the floods. The 1739 flood is the first flood described by Henckell, although his earliest writings date back to 1717. The author also described other facts (e.g. the earthquake of Lisbon in 1755 or a riot of vine farmers in 1757), but we will concentrate on his descriptions of the Douro floods until 1799. The author produced an exhaustive list of the floods that included their date and duration, the level reached by the water (very precise remarks, with the name of the inundated city districts or streets), the damages caused by the high waters and sometimes the associated meteorological phenomena.

\subsubsection{Other sources}

In addition to these two main sources, we used other descriptive documentary records to the reconstruction of the floods of the Douro River. Data were retrieved from institutional sources (ecclesiastic and municipal), from other individual sources (booklets and memoirs), manuscript and printed newspapers (Table 1):

a) Institutional sources consist of town council's minutes, Capitular Acts (S10), economic records (S1; S5) and official letters (S3; S4; S9; S11) produced by the municipal and ecclesiastic authorities of Porto. These documents often provide objective and continuous data about Pro Pluvia and Pro Serenitate rogations. These Catholic ceremonies asked for the end of the Divine punishment of drought periods (Pro Pluvia rogations) or long wet/ stormy spells (Pro Serenitate rogations). Most records consist of correspondence between religious and civil authorities and the local communities, in order to carry out expensive public actions, to "solve" problems caused by adverse weather conditions in Spain (Barriendos 1997, Fernández-Cortizo 2005); in Portugal (Alcoforado et al. 2000, Taborda et al. 2004, Silva 2017, 2019; Fragoso et al. 2018); in France (Barriendos et al., 2003; Garnier 2019); in Italy (Piervitali and Colacino, 2001); as well as in Central and South America (Prieto and Garcia Herrera 2009, Garza Merodio 2007, DomínguezCastro et al. 2015). Data from Pro Serenitate ceremonies in Porto were analysed by Silva (2017, 2019).

b) Other individual sources. Booklets and memoirs provided detailed descriptions mostly related to the great flood of December 1739 (Alão 1740; S7; S8; S6), as well as to other floods (Lopes 1796; S2; S8). This information allowed to complete and to validate long time series of damaging flood records.

c) Manuscript and printed newspapers sometimes supplied data about the damages caused by rainfall or flooding to buildings, bridges, walls or plant crops. Within this category, we must highlight two titles: the Gazeta de Lisboa, one of the main Portuguese newspapers and the one with the longest-lasting life in the history of the Portuguese press (1715-1762 and 1778-1820), and the Ano Noticioso e Histórico, a manuscript brochure written and divulged by the priest Luís Montês Matoso (17011750) between 1740 and 1754 (Silva 2019). 


\subsection{Methods}

The methodology includes (i) verification of information reliability through cross-checking of sources whenever more than one source is available; (ii) classification of flood records by combining qualitative flood damage and channel overflow into three categories (ordinary, extraordinary and catastrophic floods); and (iii) using new climate simulations to analyse the synoptic conditions of the most representative episodes.

\subsubsection{Cross-checking of sources}

As already mentioned, flood data was collected directly from contemporary historical sources. The reliability of the compiled data is generally high since most events and their dates have been confirmed by different eyewitnesses. Thus, multiple sources permit the verification of the occurrence and magnitude of floods. Moreover, some of the primary sources were not only unacquainted with each other but were also produced for different purposes.

\subsubsection{Flood categories}

Different methods and procedures have been used to extract the information contained in historical records (Brázdil et al. 2005, 2006; Kjeldsen et al. 2014). The more detailed approach involves the use of qualitative indices, often employing a scale dividing the events into a set of ordinal classes for flood severity (Barriendos et al. 2003, 2019). These classes are defined according to the damages caused by high discharges and to the level reached by the flooding (Fig.2). This allows a straightforward standardized classification of flood events.

In this paper, the hydrological extremes were classified into three categories, according to the magnitude of the flood and the severity of the damages (Brázdil et al. 2006; Kjeldsen et al. 2014; Barriendos et al. 2003, 2019). Our classification is based on Henckell's and Costa's descriptions of the water levels during floods, as well as in the administrative and ecclesiastic sources. Additionally, Henckell described precisely the level reached by the water in relation to peepholes of the walls, fountains and buildings (city plan in Fig. 2). Therefore, a three-point scale was established:

- Ordinary floods: water flooded the piers and reached the base of the wall, without significant damages $(62.9 \%$ of the cases).

- Extraordinary floods: increased water flow, with overflow up to the top of the wall, significant damages, excluding the destruction of permanent infra-structures $(20.4 \%)$.

- Catastrophic floods: increased water flow, with an extensive overflow of the valley margins and enormous damages including loss of human lives, destruction of vessels, hydraulic infrastructures, buildings, roads and agricultural fields (13\%).

- In two cases (3.7\%), it was not possible to classify the floods.

\subsubsection{Atmospheric circulation analysis}

In order to analyse atmospheric circulation conducive to Douro floods, newly available climate simulations were used. Therefore, we applied the global monthly ensemble climate reconstructions EKF400 back to 1603, which are based on assimilating instrumental data, 
documentary data and tree ring proxies into an ensemble of 30 global climate model simulations. Among the available paleo-reconstructions, the EKF400 dataset "combines the advantage of traditional reconstruction methods of being as close as possible to observations with the advantage of climate models of being physically consistent and having 3-dimensional information about the state of the atmosphere for various variables and at all points in time" (Franke et al. 2017). This reconstruction dataset includes several atmospheric variables, including some of the more relevant to investigate the dynamic features responsible for major floods, such as air pressure at sea level, the geopotential height at $500 \mathrm{hPa}$ and the precipitation amount, which is the key driving control of the floods in the study region.

\section{Results}

\subsection{Main characteristics of the floods of the Douro river in Porto, in the eighteenth century}

Floods caused by intensive and/or long-lasting rainfall in the basin of the Douro are the most frequent ones in Porto. Sudden floods may also occasionally occur. As expected in this climatic region, in which the rainfall maximum values occur between October and March (Suppl. Fig. 2), the greatest number of flood events happened in winter and autumn.

All the flood events took place between October and May. Their greatest frequency was in January (14 events, 25.9\%), followed by December $(12,22.2 \%)$ and February $(8,14.8 \%)$ (Suppl. Fig. 4). February was the month with more flood days (40 in the studied period), followed by January (36) and December (32). The time extent of the floods was variable. The majority of the flood events had a short duration (between 1 and 3 days). Only 9 floods persisted for more than 5 days, and the longest one lasted 12 days (1757) (Suppl. Fig. 5). The years 1758 and 1786 were the ones with a higher frequency of reported floods ( $=$ or $>$ than 4 events).

There was great interannual variability among the Douro floods during the eighteenth century. As we have hardly any indication of floods for the early 1700 s (which can be eventually related to a lesser amount of available documentary evidence), our study is mostly dedicated to the period 1727-1799. Flooding events were by far more frequent in the second half of the studied period. The yearly incidence and the severity of the floods are recorded in Fig. 3 based on several types of sources described in section 3 .

There were 54 historical flood events in the mouth of the Douro River within the period 1727-1799: 7 of them were catastrophic floods and 11 extraordinary ones (Fig. 3). There were not many floods recorded in the first part of the studied period, but the ones in 1727 and 1739 were classified as "catastrophic", followed by the "extraordinary" floods of 1741 and 1747. During the 1750s, 10 ordinary floods were recorded as well as an extraordinary one in 1751 . There is news of three ordinary floods in 1763 and another one in 1765, but the only recorded catastrophic flood occurred in 1769 and lasted between April 12 and 14. Earlier, in Autumn 1768, rainfall had been so intense and so prolonged that it led to Pro Serenitate prayers in October of that year, followed by processions (Silva 2017, 2019). The April 1769 rainfall and the floods had serious consequences in agriculture and possibly in human health. The causal relationship has not yet been established, but the year 1770 was the one with the highest mortality in Porto during the eighteenth century (Osswald 2008). Between 1770 and 1779, 12 floods were documented in our sources, two of which were "catastrophic" ones (1774 and 


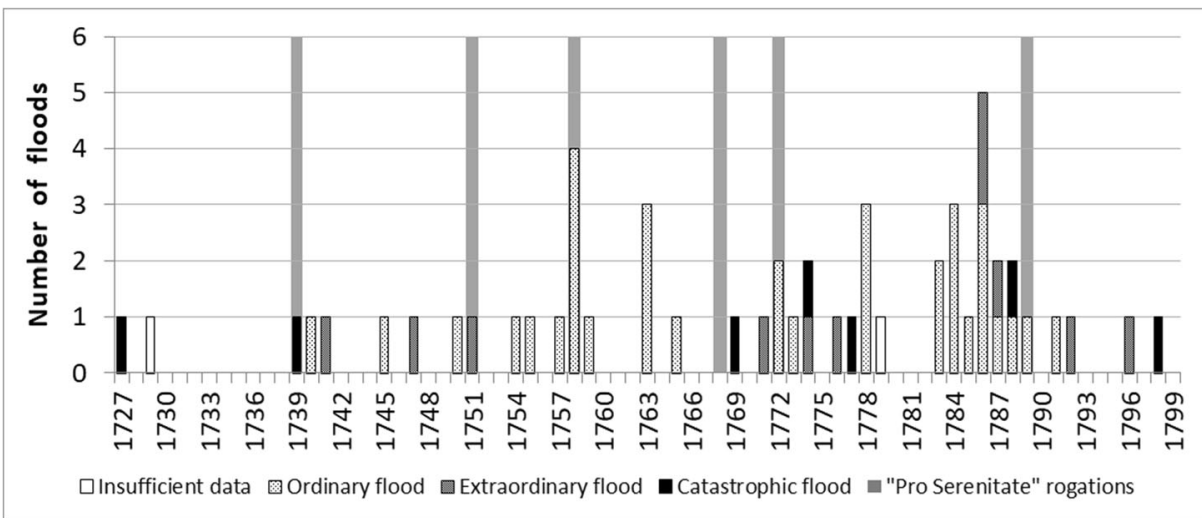

Fig. 3 Number and magnitude of the Douro floods from 1727 to 1799 and Pro Serenitate ceremonies in Porto

1777). According to Henckell, the February 1777 flood was the worse one after the 1739 flood, and it was followed by three more in 1778 and one in 1779. After a short drier period, 18 floods were reported between 1783 and 1793 (one "catastrophic" in 1788). At the end of the studied period, there are fewer accounts of floods, but the one in 1798 was considered "catastrophic". Indeed, Alcoforado et al. (2012) and Fragoso et al. (2015), based on the early Portuguese instrumental data, pointed out that the period between 1783 and 1789 was extremely rainy in Portugal. Reliable instrumental data from Porto, carried out by the physician JB Lopes, unfortunately only refer to 1792 and do not contain precipitation data (Alcoforado et al. 2012).

The occurrence of Pro Serenitate rogation ceremonies in Porto is indicated in Fig. 3. Unlike the droughts that may last for a long time and affect a large area (Fragoso et al. 2018), heavy precipitation that causes river floods are more concentrated in space and time, and the reaction of the civil and religious authorities must be faster in organizing ceremonies to ask for the end of weather inclemency. In fact, flood frequency oscillations show a reduced agreement with Pro Serenitate rogations, compiled in previous research (Silva 2017, 2019). Only 9 of the 54 floods coincide with the performance of prayers, novenas and processions in Porto to ask God for the end of intense rainfall.

\subsection{The major Douro floods in Porto during the eighteenth century}

According to the chosen flood severity index (see 3.2.2), the catastrophic floods occurred in December 1727, December 1739, April 1769, December 1774, February 1777, February 1788 and December 1798. All of them caused great human and material losses.

In this study, we will analyse in detail the floods of 1727, 1739, 1777 and 1788, on account of the levels reached by the water, the high flow discharge and their devastating human and material consequences in Porto. The vulnerability of the population against these natural hazards will be studied, as well as the measures and strategies adopted to diminish their effects.

\subsubsection{The December 1727 flood}

According to the Gazeta de Lisboa, the December 1727 flood was produced by "torrential rains" which had fallen over several days. The same newspaper mentions that "there was no 
memory of such a large flood for many years". Costa's text illustrates the behaviour of the river and the impacts of the floods as follows: "On December $28^{\text {th }} 1727$ the Douro River water was so rapid and sudden that it dragged more than 100 people, buildings, large vessels, numerous small boats, vineyards, mills and other factories, whose losses attained millions of cruzados" (Costa 1789). The Corpus Christi nuns' convent, situated close to the river, in front of the city of Porto, was partially submerged; in Porto, "from the top of the wall it was possible to touch the water with the hands" (Fig. 2). Costa adds that the impacts of the 1727 Douro flood "are still visible e.g. in some families that were once rich and that have lost everything and are now reduced to a pitiful indigence" (Costa 1789).

\subsubsection{The December 1739 flood: "The greatest one we can remember"}

The flood took place at the beginning of December as per several sources, such as newspapers, memoirs, booklets and administrative and ecclesiastic records (Table 1).

Several storms occurred in the last months of 1739: "impetuous winds, continuous rain and thunder so dreadful, that this seamed a deluge rather than a storm" (S8). Rainfall lasted from the end of September until December, "without any day of dry weather" (S7). Precipitation intensity increased further at the end of November so that on December 3, the level of the Douro River began to rise a great deal and the flood continued on December 4, 5 and 6 (Taborda 2006). Costa also mentions the 1739 flood, and he states that it was similar to the one in 1727 (Costa 1789).

The flow was so violent that it "originated waves, like the sea when it is very rough" (S7). The damages were uncounted for the river and inland. Five Portuguese, as well as four foreign vessels, sank. "Only one was unloaded, but all the others were prepared to sail off. They were all swept out to the sea and were destroyed on the nearby Atlantic coast. Fortunately, no human lives were lost as people were able to reach the Douro banks" (S7). The following days the water level decreased leaving several watercrafts ashore (Valente 1962).

In the city, from the Sé (Cathedral) to Miragaia near the harbour (Suppl. Fig. 3), the flow increased rapidly and knocked down trees, dragged goods from stores and shops and demolished tens of houses in Porto and Gaia. The city walls were destroyed in different places, as well as the pier from the Guindais stairs to the beginning of the Ribeira wharf, "in such a way that it seemed a work made by the devils" (S8). Furniture, parts of houses and mills, as well as warehouse fragments, wine barrels, olive oil bottles and wood, among other items, floated down the river (S8).

The water level went down the following weeks, but rainfall continued and caused huge damages to agriculture and consequent famine (S7). After several prayers (including ones addressed to a thaumaturgical image of Christ within the Cathedral, the Senhor de Além) (Silva 2017, 2019; Amorim 2017), a Pro Serenitate procession took place on December 23 through the streets of Porto. All brotherhoods, sororities, communities and the clergy participated in this Pro Serenitate procession. The flood was so notorious that Henckell wrote that there was no recollection of such a damaging flood (Valente 1962), but he does not indicate which floods he was refering. It must be pointed out that no great flood had occurred during the previous years; there were even Pro pluvia ceremonies in 1738 after a long drought (Fragoso et al. 2018). Similarly to these days, people did not always remember the weather as it was one or two decades earlier. The December 1739 flood was certainly a huge one, as referred also in Taborda (2006) and Pfister et al. (2010), but in the opinion of Costa (1789), it was comparable to the one of December 1727 that Henckell had not witnessed. 


\subsubsection{The February 1777 flood}

The rain that fell intensely from February 17 onwards led to an enormous increase of the Douro discharge. On the 21 st and the 22nd the river was already overflowing its channel, and on the 24th it flooded the river banks up to "the first door of the Customs House"; this level is attained only in huge floods. However, the damages were not too severe because there were few vessels anchored near Porto, and everyone took shelter on dry land (Valente 1962). This case study shows that the severity of the flood impacts is reduced when the population is less vulnerable.

\subsubsection{The February 1788 flood}

The "last and terrible flood" was registered in Henckell's and Rebelo da Costa's sources, as well as in the Lisbon newspaper, Gazeta de Lisboa (Table 1).

Intense rain had been falling in Porto from the beginning of December 1787 onwards, and the river water reached the pier; on December 23 and December 25, when precipitation was again very intense, the Douro discharge increased substantially. Water levels rose again on January 6, not on account of reported rain, but possibly due to soil saturation and the difficulty of the outward flow at the Douro mouth. Then, a great windstorm, "a terrible hurricane from the West" (Costa 1789), with thunderstorms and violent rains swept the area for 3 days (February 16 onwards). The winds toppled large trees and lifted several roofs. On February 21 and 22, water flooded the riverine districts, peaking on the 24th and 25th, "when the water rose 31 palmos (circa $6.8 \mathrm{~m}$ ) above its normal level" (Costa 1789). Then the water level lowered so slowly that at the beginning of March it had not yet reached its normal level (Valente 1962). Similar situations occurred in other places in Portugal (Fragoso et al. 2015). There was a lot of damages to buildings, stores, roads and the 114 boats and vessels anchored in the Douro: "81 Portuguese, 28 British and 1 French, among others" (Costa 1789). Three Portuguese vessels (between 150 and 360 tons) were dragged out to the ocean and destroyed against the shore. One of these ships "went downriver, with the keel upside down" (Costa 1789), demonstrating the strength of the flow. The damages could have been even worse if a few days earlier 16 vessels had not left Porto harbour, all loaded with valuable goods.

These damages occurred despite the measures taken by the population, accustomed to deal with the consequences of the high waters and violent flow. Not only did they tie the vessels to each other so that they made a wall against the violent flow, but also they held the boats with thick cables and enormous moorings to impel them in direction of areas where the flow was calmer (Costa 1789). This tireless effort made by men and women "seemed to exceed human strength" and caused the drowning of two persons (Costa 1789).

Along the banks, the consequences were was also disastrous. The Douro River flooded great part of the riverine city districts, inundated 18 streets and more than 1000 houses, some of which were ruined. Several warehouses full of wine and liqueurs were submerged up to their roofs and sand covered several streets such as the promenade of Miragaia, the Porta Nova street and the Ribeira pier (Costa 1789).

In 1788 , there was a complaint against the city administration and the public authorities (Costa 1789). If the sand accumulated during previous floods had been removed, the damages of the 1788 flood would have been smaller. The author invokes the previous floods and condemns the lack of memory of public authorities, permitting the replication of such material damages and the loss of human lives; these could have been avoided, provided that proper 
measures had been taken. He emphasizes the role of fearless women, who helped men to sustain the Douro rising waters (Costa 1789).

\subsubsection{The atmospheric situation concerning the flood events}

The monthly atmospheric panels depicted in Fig. 4 exhibit some features plausibly conducive to flooding over the northwestern regions of the Iberian Peninsula and the Douro basin. A general overview of the panels shows that the reconstructed atmospheric circulation over the Eastern North Atlantic in these flooding months was mainly controlled by low-pressure systems, presumably bringing frontal activity and wet conditions to Western Europe, including Portugal.

In December 1727, low-pressure centres dominated at sea level, southwards from Greenland. The frontal activity associated with these Atlantic cyclonic systems produced positive precipitation anomalies over the Iberian Peninsula, particularly affecting NW Iberia (top panels, Fig. 4).

In December 1739, the panels suggest the recurrent activity of strong extratropical cyclones over the NE Atlantic. These strong low-pressure systems were responsible for heavy rainfalls

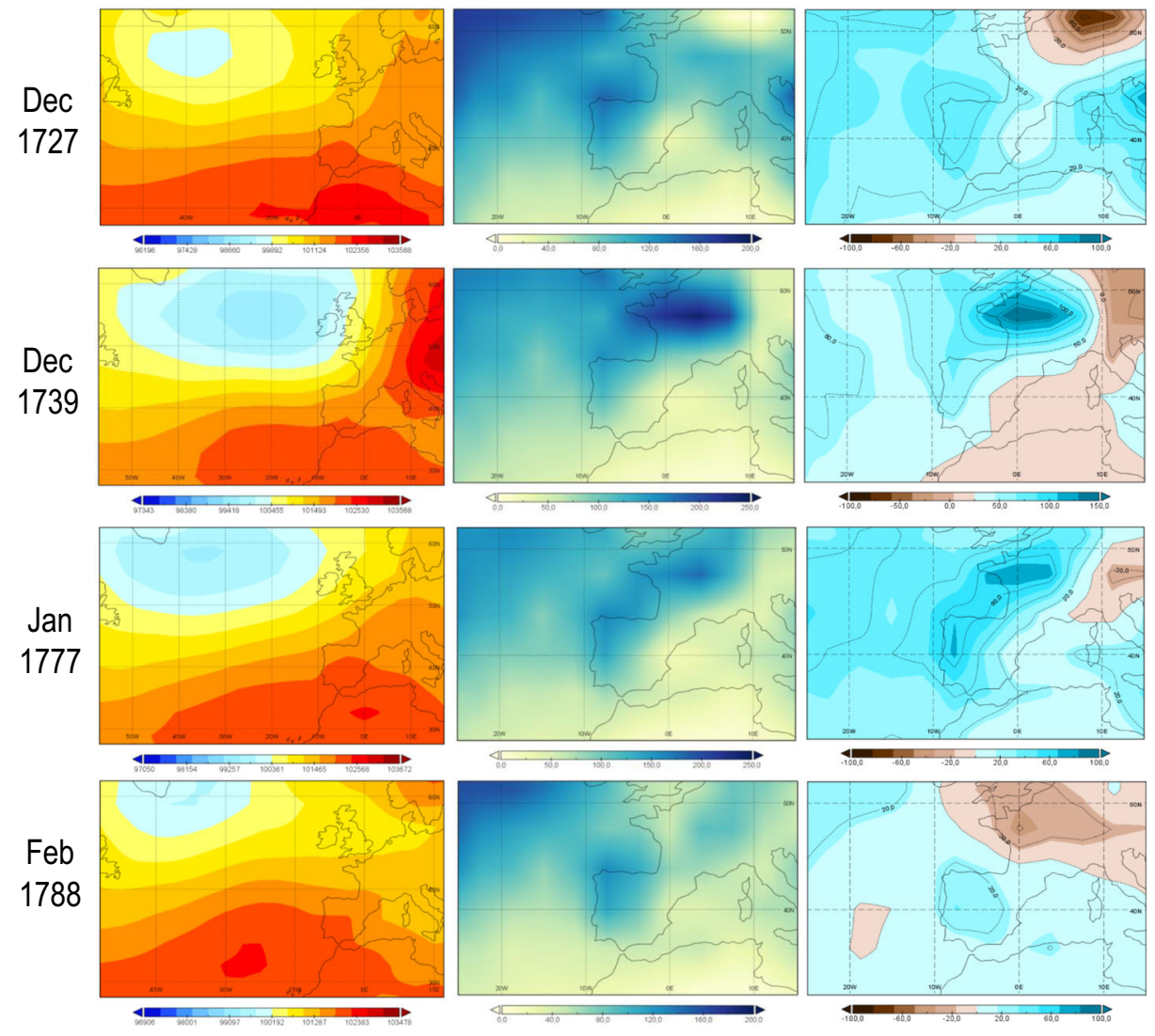

Fig. 4 Mean monthly air pressure at sea level ( $\mathrm{Pa}$, left column), total precipitation (mm, central column) and precipitation anomalies (mm, right column) for extreme floods in the Douro River (Porto region) in the eighteenth century. Data source: Franke et al. (2017) 
over Western Europe (Fig. 4). Among the Atlantic storms, the one named "Barbara" was devastating and caused intense precipitation and violent winds in Portugal (Pfister et al. 2010). The passage of successive frontal systems contributed to the accumulation of rainfall and progressive rising of Douro discharges and the heavy impacts described above.

The atmospheric context of the January 1777 floods in Douro river is also due to an intense westerly circulation over Western Europe. The repeated occurrence of large and deep lowpressure systems is consistent with the monthly mean sea level pattern illustrated in Fig. 4, where a strong pressure gradient over the Atlantic region is visible in NW Iberia, apparently ensuring frequent frontal systems moving eastwards or northeastwards. The precipitation panels (Fig. 4) depict stronger positive anomalies in France and NW Iberia (50-60 mm).

The atmospheric situation responsible for the February 1788 floods in the Douro river was described in detail in Fragoso et al. (2015). The meteorological context was similar to the other flooding events. The monthly mean sea level pattern (Fig. 4) shows more resemblance to the December 1727 floods. Interestingly, the highest reconstructed precipitation anomalies in February 1788 were limited to Western Iberia as in December 1727.

\section{Discussion}

The severity and frequency of the eighteenth-century flood events in the Douro River are analysed using documentary evidence based only on primary sources. This case study shows how historical information can improve flood knowledge, and it further confirms that the Portuguese historical archives contain sufficient information to identify and characterize floods in long-term chronologies, with abundant complementary information such as seasonality, water levels, meteorological causes and socio-economic impacts. As in other well-known case studies, the more extreme an event the more evidence is available, and the more detailed the information on its intensity, seasonality, causes and impacts.

This research work establishes the great variability of heavy precipitation in NW Portugal in the eighteenth century. More than 50 floods were recorded ( 7 of which were catastrophic ones). There were far more floods during the second half of the studied period, which is in accordance with Blöschl et al. (2020), who state that one of the "flood-rich" period in Western and southern Europe was 1760-1800. Moreover, a clear increase in the frequency and severity of floods in the 1770s and, above all, in the 1780s was identified. It could either be a consequence of a real climatic trend ('Maldá' Anomaly, Barriendos and Llasat, 2003; Fragoso et al. 2015) or the consequence of random factors and/or due to changes in the environmental conditions and socio-economic system. Besides, no long-term trend on the frequency of the Douro floods in the nineteenth and twentieth centuries was detected (Santos et al. 2018), and peak flows of the Douro floods have been declining in the last five decades (Soares and Bateira 2020). This decrease may be partly due to flow regularization provided by dams, although the same authors highlight that Porto and Vila Nova de Gaia riversides will always be prone to flooding.

Flood events in the Iberian Peninsula show a high spatial and temporal variability caused by its orographic complexity and by a large number of atmospheric processes originating precipitation, which make it difficult to compare the data between different regions.

Within Portugal, there is a coincidence in the occurrence of severe floods over a broader region only under the influence of very intense westerly low-pressure systems, for example, on the occasion of intensive rains in December 1739, which affected the rivers Douro, Mondego and Tagus (Fig. 4) (Benito et al. 2003; Taborda 2006; Pfister et al. 2010). 
We also found simultaneous pluviometric conditions in Western Galicia (GonzálezFernández 2000; Fernández-Cortizo 2005; Fernández-Cortizo and González-Lopo 2015) and temporal matches of floods at Zamora (CTEI 1983; Álvarez-Vázquez 1986) and at the Ebro valley (Barriendos et al. 2019). Alvarez Vásquez (1986) describes Pro Serenitate processions in Zamora (in the mid basin of the Douro River, $240 \mathrm{~km}$ from Porto, Fig. 1) and indicates the years when intense rainfall and severe floods occurred. The following are coincident with the floods at the Douro mouth: 1729, 1739, 1740, 1745, 1757, 1758, 1769, 1787 and 1788. The river discharge was fed not only by heavy rainfall in NW Portugal but also by water proceeding from upstream in Spain. In Galicia, several periods of the eighteenth century were classified as very rainy, based on Pro Serenitate rogation ceremonies celebrated in the cities of Pontevedra and Santiago de Compostela (Fernández-Cortizo 2005 and Fernández-Cortizo and González-Lopo 2015). Some of these rainy periods are consistent with floods of the Douro River. The most important occurred in 1727, 1739/41, 1745, 1747, 1750/1751, 1759, 1763, 1768/1769, $1771 / 1774,1776 / 1778,1783,1788 / 1789$ and 1796; the penultimate was characterized by Pro Serenitate rogations during almost all the year-round. Furthermore, Pro Serenitate prayers were also celebrated in Vigo in the years affected by large floods in the Douro River, namely, in 1729, 1739, 1751, 1768/1769, 1777 and 1791 (González-Fernández 2000).

Regarding the Tagus basin, Benito et al. (2003) differentiated two periods throughout the eighteenth century with increased occurrence of flooding: the first one occurred between 1730 and 1760 and the second one between 1780 and 1810. The first maximum does not match the flow conditions of the Douro River for which we found a significant decrease in floods between 1730 and 1738 and a long period without catastrophic floods between 1740 and 1768 . On the contrary, the second maximum is very well documented in many Portuguese historical sources (Fragoso et al. 2015).

Concerning the north-eastern part of the Iberian Peninsula, Barriendos et al. (2019) describe a period between 1774 and 1793, in which hydrologic extremes and catastrophic floods show a notable increase in frequency, in good agreement with flood frequency of the Douro in Porto. A similar situation happened in the Ebro basin, and particularly in its Pyrenean tributaries, when the frequency of large floods increased during the period 1770-1790 but, mainly during spring, probably triggered by water from melted snow (Benito et al. 2003).

Hardly any floods occurred in other SW European countries simultaneously with the ones at the Douro River in Porto. As Camuffo et al. (2003) point out, the most intense rains that lead to river flooding in Iberia and the central part of the Mediterranean are caused by different circulation types: in western Iberia, floods of the large rivers are due to zonal circulation and frequent passages of frontal disturbances, whereas in central Italy, most heavy rains are due to deep depressions formed within the meridional circulation. Indeed, the atmospheric context of the Douro floods is linked with the activity of strong extratropical cyclones over the eastern Atlantic Ocean, steering powerful storms to Western Europe. Numerous studies focused on the meteorological controls that favour this anomalous intensity of the Atlantic extratropical cyclones (Fink et al. 2012; Pinto et al. 2009), pointing out an enhanced north-south tropospheric temperature contrast associated with a very strong upper-tropospheric jet stream directed towards Europe. The zonal flux may extend exceptionally eastwards towards Southern France and Italy. In Suppl. Table 1, a comparison between dates of floods at the Douro mouth (Porto) and several other rivers/places in Spain and Italy is carried out, as an attempt to verify the time discrepancy of floods during the study period. Effectively, among the 54 major floods of the Douro, there are only three floods that occurred during the same month in the Arno (Florence) in December 1758 and the Tiber (Rome), in December 1784 and January 
1786 (Camuffo and Enzi, 1996; Caporali et al., 2005), whereas there are some more coincidences with the Douro and Tagus Rivers floods, as pointed out above. Furthermore, no Italian flood coincides with any "catastrophic" flood of the Douro; only in January 1786, an "extraordinary" flood of the Douro occurred at the same time as the one of the Tiber in Rome. The other two (Arno, December 1758, and Tiber, December 1784) coincide with "ordinary" floods of the Douro. Monthly ensemble climate reconstructions EKF400 (not shown) indicate that for the above referred months, the air pressure at sea level and specially the geopotential height at $500 \mathrm{hPa}$ are consistent with the ones with rapid western flow, extending eastwards to southern Europe.

Moreover, there is no rigorous evidence found about the impact of floods on mortality. The sources cite numbers as dissimilar as 100 dead during the 1727 floods (figure probably too straightforward and symbolic), and only two people died during the 1788 flood. The greatest impacts were felt within the community of merchants (some of them foreigners), boat owners who frequently entered and left the Douro to Brazil and different parts of Europe. That is why Henckell watches vigilantly (and notes down) the rise of the waters, the winds, the tides and the boat conditions in the Douro. As explained above, Pro Pluvia and Pro Serenitate processions and prayers are mechanisms used by catholic populations to seek help against natural meteorological disasters. However, Pro Serenitate ceremonies are rather few in Porto, when compared with Galicia (González-Fernández 2000; Fernández-Cortizo 2005; FernándezCortizo and González-Lopo 2015), where the precipitation regime is similar. It seems that the inhabitants of Porto could deal more easily with extreme rainfall than with droughts.

The long records of historical floods help to put into context the recent floods, to construct longer series, to improve models and projections and, in the case of studies in smaller areas, to provide elements for land planning and to determine the areas more prone to flood hazard (Luino et al. 2002).

\section{Conclusion}

The use of a great number of documentary sources permitted to extend the flood series into the eighteenth century and to verify the great interannual precipitation variability in NW Portugal. Ignacio Henckell's "Lembranças", covering the period between 1739 and 1799, were the leading thread of the present research. This study confirms that the inhabitants of Porto had to learn to live with the Douro River, both with the benefits it creates (mainly related to trade) and also with the disasters it originated. A total of 54 floods were identified at the Douro river mouth, including seven classified as catastrophic $(1727,1739,1769,1774,1777,1788$ and 1798). The floods occurred mainly in autumn and winter, and most of them lasted between 1 and 3 days. The floods were due to heavy rainfall and aggravated by the narrowness of the river valley, the bottleneck form of the Douro estuary, the accumulation of sand, the imperviousness of the river banks and the ocean tide oscillations. The intense traffic of watercraft in the Douro mouth contributed significantly to increase the impacts of the high waters. Four catastrophic floods are described in detail $(1727,1739,1777,1788)$. In all cases, the intense precipitation was due to strong extratropical cyclones. Analogies were established with Galicia and the mid-Douro valley, although hardly any floods occurred in other SW European countries simultaneously with the ones of the Douro in Porto. The longer series of extreme overflows also provides data useful for land planning in these flood-prone areas. 
Supplementary Information The online version contains supplementary material available at https://doi.org/ 10.1007/s10584-021-03039-7.

Acknowledgements The authors are grateful to the reviewers for many valuable suggestions, which helped improve the manuscript and for sending some additional data referring to Italian rivers. We would also like to thank Teresa Sutcliffe for checking the English language.

Authors' contributions MJ Alcoforado structured and wrote the first drafts of this paper and prepared the final version with the comments and suggestions of all the authors. Besides commenting on the drafts, LP Silva investigated and analysed the manuscript and printed sources, made 5 figures and the tables and carried out literature review, and the formatting procedures; I Amorim and JC Garcia supervised source prospecting and analysis and provided other sources and references; M Fragoso prepared the section on atmospheric circulation based on EKF400 reanalysis and made Fig. 4 and Suppl. Fig.2.

Funding This study stems in part from a previous project "Reconstruction and model simulations of past climate in Portugal, using documentary and early instrumental sources"-KlimHist, financed by national funds from FCT [PTDC/AAC-CLI/119078/2010] [UID/GEO/00295/2013]. The research was also funded by Fundação para a Ciência e Tecnologia (FCT) - Pluriannual financing UIDB/00295/2020 and UIDP/00295/2020.

Data availability Data will be available on demand, in view of collaborative work.

Code availability Not applicable.

\section{Declarations}

Ethical approval This is an original manuscript, not submitted or published elsewhere. Proper acknowledgements to other works has been given.

Consent to participate All authors agreed to participate in this study.

Consent for publication All authors agreed with the contents of this paper.

Conflict of interest The authors declare that have no conflicts of interest.

Open Access This article is licensed under a Creative Commons Attribution 4.0 International License, which permits use, sharing, adaptation, distribution and reproduction in any medium or format, as long as you give appropriate credit to the original author(s) and the source, provide a link to the Creative Commons licence, and indicate if changes were made. The images or other third party material in this article are included in the article's Creative Commons licence, unless indicated otherwise in a credit line to the material. If material is not included in the article's Creative Commons licence and your intended use is not permitted by statutory regulation or exceeds the permitted use, you will need to obtain permission directly from the copyright holder. To view a copy of this licence, visit http://creativecommons.org/licenses/by/4.0/.

\section{References}

Aires C, Pereira DI, Azevedo TM (2000) Inundações do rio Douro: dados históricos e hidrológicos. I Jornadas do Quarternário da APEQ, FLUP, Porto

Alcoforado MJ, Nunes MF, Garcia JC, Taborda JP (2000) Temperature and precipitation reconstruction in southern Portugal during the late maunder minimum (AD 1675-1715). Holocene 10(3):333-340. https://doi. org/10.1191/095968300674442959

Alcoforado MJ, Vaquero JM, Trigo RM, Taborda JP (2012) Early Portuguese meteorological measurements (18 ${ }^{\text {th }}$ century). Clim Past 8:353-371. https://doi.org/10.5194/cp-8-353-2012 
Álvarez-Vázquez JA (1986) Drought and rainy periods in the province of Zamora in the 17th, 18th, and 19th centuries. In: Lopez Vera F (ed.) Quaternary climate in Western Mediterranean. Universidad Autónoma de Madrid, pp 221-235

Amorim I, Garcia JC, Silva LP (2017) As cheias do rio Douro no Porto (Portugal) do século XVIII. SÉMATA 29:185-217

Antón L, Rodés A, De Vicente G et al (2012) Quantification of fluvial incision in the Duero basin (NW Iberia) from longitudinal profile analysis and terrestrial cosmogenic nuclide concentrations. Geomorphology 165166:50-61. https://doi.org/10.1016/j.geomorph.2011.12.036

APA (2012) Agência Portuguesa do ambiente - plano de gestão da Região Hidrográfica do Douro. Lisboa

Araújo MAVC, Mazzolari A, Trigo-Teixeira A (2013) An object oriented mesh generator: application to flooding in the Douro estuary. J Coast Res 65:642-647. https://doi.org/10.2112/SI65-109.1

Barriendos M (1997) Climatic variations in the Iberian Peninsula during the late maunder minimum (AD 16751715): an analysis of data from rogation ceremonies. Holocene 7(1):105-111. https://doi.org/10.1177/ 095968369700700110

Barriendos M, Cœur D, Lang M et al (2003) Stationarity analysis of historical flood series in France and Spain $\left(14^{\text {th }}-20^{\text {th }}\right.$ centuries). Nat Hazards Earth Syst Sci 3:583-592. https://doi.org/10.5194/nhess-3-583-2003

Barriendos M, Gil-Guirado S, Pino D et al (2019) Climatic and social factors behind the Spanish Mediterranean flood event chronologies from documentary sources $\left(14^{\text {th }}-20^{\text {th }}\right.$ centuries). Glob Planet Chang 182:102997. https://doi.org/10.1016/j.gloplacha.2019.102997

Barriendos M, Llasat MC (2003) The case of the 'Maldá' anomaly in the Western Mediterranean Basin (ad17601800): an example of a strong climatic variability. Clim Chang 61:191-216. https://doi.org/10.1023/A: 1026327613698

Barriendos M, Rodrigo FS (2006) Study of historical flood events on Spanish rivers using documentary data. Hydrol Sci J 51(5):765-783. https://doi.org/10.1623/hysj.51.5.765

Benito G, Díez-Herrero A, Fernández de Villalta M (2003) Magnitude and frequency of flooding in the Tagus basin (central Spain) over the last millennium. Clim Chang 58:171-192. https://doi.org/10.1023/A: 1023417102053

Bertola M, Viglione A, Lun D et al (2020) Flood trends in Europe: are changes in small and big floods different? Hydrol Earth Syst Sci 24:1805-1822. https://doi.org/10.5194/hess-24-1805-2020

Blöschl G, Kiss A, Viglione A et al (2020) Current European flood-rich period exceptional compared with past 500 years. Nature 583:560-566. https://doi.org/10.1038/s41586-020-2478-3

Blöschl G, Hall J, Viglione A et al (2019) Changing climate both increases and decreases European river floods. Nature 573:108-111. https://doi.org/10.1038/s41586-019-1495-6

Brázdil R, Kundzewicz ZW, Benito G (2006) Historical hydrology for studying flood risk in Europe. Hydrol Sci J 51:739-764. https://doi.org/10.1623/hysj.51.5.739

Brázdil R, Pfister C, Wanner H et al (2005) Historical climatology in Europe - the state of the art. Clim Chang 70: 363-430. https://doi.org/10.1007/s10584-005-5924-1

Camuffo D, Enzi S (1996) The analysis of two bi-millenary series: Tiber and Po river floods. In: Jones PD, Bradley RS, Jouzel J (ed.) Climatic Variations and Forcing Mechanisms of the last 2000 years. NATO ASI, global environmental change, Vol. 41, springer, Stuttgart, pp. 433-450

Camuffo D, Sturaro G, Benito G (2003) An opposite flood pattern teleconnection between the Tagus (Iberian Peninsula) and the Tiber (Italy) rivers during the last 1000 years. In: Thorndycraft VR et al (ed) Palaeofloods, Historical Data and Climatic Variability. Madrid: 295-300

Caporali E, Rinaldi M, Casagli N (2005) The Arno river floods. Giornale di Geologia Applicata 1:177-192. https://doi.org/10.1474/GGA.2005-01.0-18.0018

Cœur D, Lang M (2008) Use of documentary sources on past flood events for flood risk management and land planning. C R Geoscience 340(9-10):644-650. https://doi.org/10.1016/j.crte.2008.03.001

Conceição TE (2008) Impacto das acções antropogénicas no comportamento sedimentar do rio Douro. University of Aveiro, Master Dissertation http://hdl.handle.net/10773/2338

CTEI (1983) Comisión Técnica de Inundaciones - Cuenca del Duero. Estudio de Inundaciones Históricas. Mapas de Riesgos Potenciales, Madrid

Daveau S (1977) Répartition et rythme des précipitations au Portugal. Memórias do Centro de Estudos Geográficos, 3, Lisboa

Domínguez-Castro F, Villacís M, Vaquero JM et al (2015) Reconstructing climate of Ecuador: potential of documentary sources. XIX INQUA Congress, Nagoya

Fernández-Cortizo C (2005) ¿Galicia, el hambre entra nadando? Rogativas, clima y crisis de subsistencias en la Galicia litoral sudoccidental en los siglos XVI-XVIII. SÉMATA 17:259-298

Fernández-Cortizo C, González-Lopo DL (2015) Bajo la protección del cielo: cambio climático y abastecimiento urbano en Santiago de Compostela. Actas del VII Congresso AISU, Padova (in press) 
Fink AH, Pohle S, Pinto JG, Knippertz P (2012) Diagnosing the influence of diabatic processes on the explosive deepening of extratropical cyclones. Geophys Res Lett 39(7):L07803. https://doi.org/10.1029/ 2012GL051025

Fragoso M, Garraça MG, Alcoforado MJ (2018) Droughts in Portugal in the $18^{\text {th }}$ century: a study based on newly found documentary data. Int J Climatol 38(15):5522-5541. https://doi.org/10.1002/joc.5745

Fragoso M, Marques D, Santos JA et al (2015) Climatic extremes in Portugal in the 1780 s based on documentary and instrumental records. Clim Res 66:141-159. https://doi.org/10.3354/cr01337

Franke J, Brönnimann S, Bhend J, Brugnara Y (2017) A monthly global paleo-reanalysis of the atmosphere from 1600 to 2005 for studying past climatic variations. Scientifica Data 4:170076. https://doi.org/10.1038/sdata. 2017.76

Garnier E (2019) Lessons learned from the past for a better resilience to contemporary risks. Disaster Prev Manag 28:786-803. https://doi.org/10.1108/DPM-09-2019-0303

Garza-Merodio G (2007) Climatología histórica: las ciudades mexicanas ante la sequía (siglos XVII al XIX). Investigaciones Geográficas 63:77-92

Glaser R, Riemann D, Schönbein J et al (2010) The variability of European floods since AD 1500. Clim Chang 101:235-256. https://doi.org/10.1007/s10584-010-9816-7

González-Fernández JM (2000) Crisis de subsistencias y epidémicas en las villas de Vigo y Bouzas (1680-1820). Boletín del Instituto de Estudios Vigueses 6:87-105

Hall J, Arheimer B, Aronica GT et al (2015) A European flood database: facilitating comprehensive flood research beyond administrative boundaries. Proc IAHS 370:89-95. https://doi.org/10.5194/piahs-370-892015

Hall J, Arheimer B, Borga M et al (2014) Understanding flood regime changes in Europe: a state-of-the-art assessment. Hydrol. Earth Syst. Sci.18:2735- 2772. https://doi.org/10.5194/hess-18-2735-2014

Jesus M (2003) Morfodinâmica do cabedelo da Foz do Rio Douro. University of Porto, Master Dissertation https:/hdl.handle.net/10216/10640

Kjeldsen TR, MacDonald N, Lang M et al (2014) Documentary evidence of past floods in Europe and their utility in flood frequency estimation. J Hydrol 517:963-973. https://doi.org/10.1016/j.jhydrol.2014.06.038

Luino F, Belloni A, Padovan N et al (2002): Historical and geomorphological analysis as a research tool for the identification of flood-prone zones and its role in the revision of town planning: the Oglio basin. 9th Congress of the IAEG, Durban, pp 191-200

Luo CZ (1987) Investigation and regionalization of historical floods in China. J Hydrol 96(1-4):41-51

Osswald H (2008) Nascer, Viver e Morrer no Porto Seiscentista. University of Porto, PhD Dissertation

Pfister C, Garnier E, Alcoforado MJ et al (2010) The meteorological framework and the cultural memory of three severe winter-storms in early eighteenth-century Europe. Clim Chang 101:281-310. https://doi.org/10.1007/ s10584-009-9784-y

Piervitali E, Colacino M (2001) Evidence of drought in western Sicily during the period 1565-1915 from liturgical offices. Clim Chang 49:225-238. https://doi.org/10.1023/A:1010746612289

Pinto JG, Zacharias S, Fink AH et al (2009) Factors contributing to the development of extreme North Atlantic cyclones and their relationship with the NAO. Clim Dyn 32:711-737. https://doi.org/10.1007/s00382-0080396-4

Prieto MR, García-Herrera R (2009) Documentary sources from South America: potential for climate reconstruction. Palaeogeogr Palaeoclimatol Palaeoecol 281(3-4):196-209. https://doi.org/10.1016/j.palaeo.2008. 07.026

Santos M, Fragoso M, Santos JA (2018) Damaging flood severity assessment in northern Portugal over more than 150 years (1865-2016). Nat Hazards 91:983-1002. https://doi.org/10.1007/s11069-017-3166-y

Silva LP (2017) O clima do Noroeste de Portugal, no século XVIII, através das preces e procissões Pro Pluvia e Pro Serenitate. In: Alberola Romá A (ed.) Riesgo, desastre y miedo en la península Ibérica y México durante la Edad Moderna. Publicacions de la Universitat d'Alacant, pp 151-180

Silva LP (2019) O clima do Noroeste de Portugal (1600-1855): dos discursos aos impactos. University of Porto, $\mathrm{PhD}$ Dissertation https://hdl.handle.net/10216/121851

Soares L, Bateira C (2020) Geomorphology in a world cultural heritage site: the city of Porto. In: Vieira G et al (eds) Landscapes and landforms of Portugal. World Geomorphological Landscapes, Springer Nature Switzerland. https://doi.org/10.1007/978-3-319-03641-0_22

Taborda JP (2006) O Temporal de 3 a 6 de Dezembro de 1739 em Portugal. Reconstituição a partir de fontes documentais descritivas. Finisterra 82:73-86. https://doi.org/10.18055/Finis1450

Taborda JP, Alcoforado MJ, Garcia JC (2004) O clima do Sul de Portugal no século XVIII. In: Reconstituição a partir de fontes descritivas e instrumentais. Centro de Estudos Geográficos, Lisboa http://clima.ul.pt/images/ pdf/pub/b_mja_2004_climasulportugal.pdf 
Tato JF (1966) As Cheias do Rio Douro. In: GABINETE DE HISTÓRIA DA CIDADE DA CÂMARA

MUNICIPAL DO PORTO (ed) O rio e o mar na vida da cidade: Exposição documental, Câmara Municipal, Porto, pp. 156-177

Velhas E (1997) As cheias na área urbana do Porto: risco, percepção e ajustamentos. Territorium 4:49-62

\section{Historical sources}

\section{Printed Sources}

Alão MLM (1740) Successo lamentavel da destruiçam do Porto, e seus suburbios acontecido no fatal mes de Dezembro de 1739. S.n, Porto

Costa AR (1789) Descripção topografica, e historica da Cidade do Porto. Officina de Antonio Alvarez Ribeiro, Porto

Gazeta de Lisboa, 1728 (n. ${ }^{\circ}$, 22 January); 1739 (n. ${ }^{\circ} 50,10$ December); 1788 (n. ${ }^{\circ} 11,11$ March; n 14,1 April)

Valente V (1962) "Lembranças” de Inácio António Henckell, comerciante portuense do século XVIII. O Tripeiro 8:225-229

Lopes JB (1796) Anno Medico. Na Offic. de Viuva Mallen Filhos e Companhia, Porto

\section{Manuscript sources}

S1. Arquivo Histórico Municipal do Porto, Cofre dos bens do concelho, A-PUB/3458-3461.

S2. Arquivo Distrital de Braga, Manuscritos do Fundo Geral, Livro curioso..., Ms. 341.

S3. Arquivo Distrital do Porto, Cabido da Sé do Porto, Cartas e ofícios vários, PT/ADPRT/DIO/CABIDO/ 012/1612-1615.

S4. Arquivo Histórico Municipal do Porto, Próprias, A-PUB/791.

S5. Arquivo Distrital do Porto, Cabido da Sé do Porto, Livro de benesses, PT/ADPRT/DIO/CABIDO/010004/1300-1321.

S6. Biblioteca Nacional de Portugal, Manuscritos Reservados, Braga - Historia desde 1700 até 1777. Appendiz em 1806, Cod.682.

S7. Biblioteca Pública Municipal do Porto, Manuscritos, [Miscelânea principalmente histórica], Ms.72.

S8. Biblioteca Pública Municipal do Porto, Manuscritos, Miscellanea Politica e Juridica, Ms.545.

S9. Arquivo Distrital do Porto, Cabido da Sé do Porto, Livro Negocios da Sé Vaga de 1717, PT/ADPRT/ $\mathrm{DIO} / \mathrm{CABIDO} / 011 / 1622$.

S10. Arquivo Histórico da Santa Casa da Misericórdia do Porto, Livros de lembranças das deliberações da Mesa da Misericórdia, Série D/Banco 8/Livro 7.

S11. Arquivo Episcopal do Porto, Indice de Pastoraes, 85.

Publisher's note Springer Nature remains neutral with regard to jurisdictional claims in published maps and institutional affiliations.

\section{Affiliations}

\section{Maria João Alcoforado ${ }^{1}$ - Luís Pedro Silva ${ }^{2}$ • Inês Amorim ${ }^{3} \cdot$ Marcelo Fragoso $^{1} \cdot$ João Carlos Garcia ${ }^{4}$}

1 Centre for Geographical Studies, Institute of Geography and Spatial Planning (IGOT-UL), Universidade de Lisboa, R. Branca Edmée Marques, Lisbon 1600-276, Portugal

2 Transdisciplinary Research Centre "Culture, Space and Memory" (CITCEM), University of Porto, Porto, Portugal

3 Transdisciplinary Research Centre "Culture, Space and Memory" (CITCEM), Department of History, Political and International Studies, University of Porto, Porto, Portugal

4 Faculty of Arts, University of Porto, Porto, Portugal 